\title{
Türk Cumhuriyetlerinde Kadın Sorunsalı: Uluslararası Raporlar Işığında Türk Cumhuriyetlerinde Kadınların Mevcut Durumu*
}

Bahar Özsoy**

\begin{abstract}
Öz
XX. yüzyılın sonlarında Sovyetlerin dağılması ile birlikte teker teker bağımsızlığını kazanan Orta Asya ve Kafkasya ülkelerinde, aradan geçen çeyrek asırda önemli siyasi, ekonomik, toplumsal değişimler yaşanmıştır. Özellikle Türk Cumhuriyetlerinde ekonomik ve toplumsal alanda meydana gelen çözülmeler, kadınların yaşamlarını derin bir biçimde etkilemiş, kadınların mevcut konumları doğu-batı, eski-yeni, istikrarkarışıklık bağlamında şekillenmiştir. Çalışmada, ulusal bağlamda Türkiye, Azerbaycan, Kazakistan, Kırgızistan, Türkmenistan, Özbekistan'da cinsiyet eşitliğini sağlamaya yönelik çalışma ve uygulamalar, uluslararası bağlamda ise son yayımlanan İnsani Gelişme Raporu (Human Development Report) ve Küresel Cinsiyet Eşitsizliği Raporundaki (Global Gender Gap Report) kadınlarla ilgili veriler değerlendirilmiştir.
\end{abstract}

\section{Anahtar Kelimeler}

Türk Cumhuriyetleri, Cinsiyet Eşitsizliği Endeksi, İnsani Gelişme Raporu.

Geliş Tarihi: 20 Ekim 2016 - Kabul Tarihi: 01 Mart 2017

Bu makaleyi şu şekilde kaynak gösterebilirsiniz:

Özsoy, Bahar (2019). "Türk Cumhuriyetlerinde Kadın Sorunsalı: Uluslararası Raporlar Işığında Türk Cumhuriyetlerinde Kadınların Mevcut Durumu”. bilig - Türk Dünyası Sosyal Bilimler Dergisi 89: 171-192.

** Doktora Öğrencisi, Bakü Devlet Üniversitesi, Uluslararası İlişkiler Bölümü - Bakü/Azerbaycan ORCID ID: https://orcid.org/0000-0002-6667-6789

bhr_ozsoy_27@hotmail.com 


\section{Giriş}

1917 yılında gerçekleşen Bolşevik Devrimi sonrasında Sovyetler Birliğine bağlanan Orta Asya Devletlerindeki nüfusun yaşamı oldukça değişime uğramıştır. Bu dönemde, Orta Asya kadınları Lenin tarafından Sovyet baskısı altındaki en çok ezilen kadınlar olarak görülmüştür (Kocaoğlundan aktaran Blackburn 2011: 171). Erken dönem Sovyetlerde, kadınlar üzerinde dinin baskısını azaltmak ve onları belirli cinsiyet rollerinden "kurtarmak" çabaları göze çarpmaktadır. Bu durum Orta Asya’da bunu kabul edenler ve buna direnenler gibi bir ayrımın doğmasına neden olmuştur (Blackburn 2011: 10). Devrim sonrasında çıkarılan kararnamelerle siyasi ve toplumsal yaşamda kadın ve erkek eşitliği sağlanmaya çalışılmıştır. Bu bağlamda kadınlara tam oy hakkı tanınmış, aile reislerinin otoritesine son verilmiş ve kadınlar eşit ödeme, eşit çalışma, ücretli doğum izni gibi haklar elde etmişlerdir (Rosenberg 1990: 100). 1924 yılında, evlenen kızlara ödenen kalym uygulaması yasaklanmış, zorla evlendirmelere karşı cezai işlemler öngörülmüsstür. Ancak, yasal anlamdaki tüm çabalara rağmen, Sovyet dönemi Orta Asya’da kadın erkek eşitliği pratikte sağlanamamıştır. Buna göre kadınlar, erkeklerin aldıkları ücretlerin yalnızca üçte birini alabilmiş, önemli görülen pozisyonlara erkekler getirilmiş, erkeklerin savaş ve zorunlu çalışma kamplarına gönderildiği zamanlarda ise kadınlar ağır çalışma şartlarına maruz kalmışlardır (Uludağ ve Serin 1990). Türk Cumhuriyetlerinde Sovyetlerin uyguladığı asimilasyon politikasına rağmen, bir takım gelenek ve görenekler, Türk Cumhuriyetlerinde kadınların toplumsal yaşamdaki konumlarını etkilemeye devam etmiştir. Örneğin, dul kadının ölen kocasının erkek kardeşi ile evlenme zorunluluğuna göçebe olan Kazak, Kırgız ve yarı göçebe olan Türkmenlerde varlı̆̆ını sürdürmüştür (Rizvanova 2012: 5).

Sovyetlerin çöküşü ile birlikte ise, bağımsızlığını kazanan beş ülkede (Azerbaycan, Kazakistan, Kırgızistan, Türkmenistan, Özbekistan), toplam 55 milyona yakın insan için koşullar önemli şekilde değişmiştir. Bağımsızlıkla birlikte ekonomik sorunların baş gösterdiği ülkelerde, Sovyetlerden kalan uygulamalar ve kurumlar hızla tasfiye edilirken, yoksulluk önemli bir sorun olarak ortaya çıkmış; sonuçta kadınlar, işlerini; cinsiyet kotaları, eğitim hakları ve çocuk bakımı gibi siyasi, sosyal ve ekonomik haklarını kaybeden ilk grup olmuştur (Blackburn 2011: 1). Örneğin 1991-2007 arasında Kırgızistan'daki çalışma yaşındaki kadınlar arasında aktif ekonomik faaliyetler \%81,6'dan \%42,3'e 
düşmüştür (İbraeva, Moldosheva, Niyazova 2011: 5). İşsizlik sonucunda kadınlar daha çok ev ekonomisi ile uğraşmaya başlamış, bu da kadınların kamusal alandan çekilerek özel alana kapatılması ile sonuçlanmıştır. Yine, Özbekistan'da \%2,5 olan bilim kadını oranı 1980-1994 yılları arasında \%1,2'ye düşmüştür (Şafakcı t.y.: 4). Günümüzde ise, genel olarak Orta Asya ve Kafkasya’da kadınların konumları Sovyet etkisi, geleneksel değerler ve ülkelerin sosyo-ekonomik koşullarına bağlı olarak şekillenmektedir.

Görüldüğü gibi, Sovyetlerin dağılması ile birlikte, Orta Asya ve Kafkasya’daki Türk Cumhuriyetlerinde kadınlar siyasi, ekonomik ve toplumsal alanda görece daha zor koşullarla karşı karşıya kalmışlardır. Günümüzde hukuksal anlamda hiçbir kısıtlama olmamasına karşın, bu ülkelerde kadınlar ulusal parlamentolarda daha az oranda temsil edilmekte, istihdama daha az katılmakta, erkeklere oranla enformel sektörde daha fazla görülmekte, erkeklerden daha az ücret almakta, kamusal görünürlükleri erkeklere oranla daha kısıtlı olmaktadır. Bahsi geçen ülkelerin Türkiye ile güçlü tarihsel, kültürel bağları nedeniyle, gelenek ve görenekler kadınların toplumsal yaşamlarını benzer ölçülerde etkilemiş; sosyal yaşamda kadın ikincil statüden kurtulamamıştır.

\section{Türk Cumhuriyetlerinde Kadınların Mevcut Konumları}

\section{Türkiye}

1923 yılında Türkiye Cumhuriyetinin kuruluşu ile birlikte yasalarda kadın ve erkelere yönelik düzenlemelerle kadın-erkek eşitliği sağlanmaya çalışılmış; kadınlar eğitim-öğretim, seçme ve seçilme, çalışma hakkı gibi bir takım haklara sahip olmuşlardır. 1930 yılında Türkiyede, belediye seçimlerinde oy kullanma hakkına sahip olan kadınlar, 1934 yılında hem seçme hem seçilme hakkını elde etmişlerdir.

Ülke nüfusunun yarıya yakını $(\% 49,8)$ kadınlardan oluşan Türkiye'de kadın-erkek eşitliği anayasa ve yasalarla güvence altına alınmış, oluşturulan kurumlarla kadın sorunlarına çözüm getirilmeye çalışılmıştır. Cumhuriyetin ilanı sonrasında toparlanma sürecinin ardından, kadın-erkek eşitliğini sağlamak amacıyla, uluslararası alandaki anlaşma ve sözleşmelere taraf olunmuştur. Bu bağlamda, 1985 yılında "Birleşmiş Milletler Kadınlara Karşı Her Türlü Ayrımcılığın Önlenmesi Sözleşmesi” (CEDAW) imzalanmış, 1990 yılında Sosyal Hizmetler ve Çocuk Esirgeme Kurumu Genel Müdürlüğü bünyesinde, şiddete uğrayan kadınlara ve çocuklara destek sağlamak amacıyla ilk 
kadın konukevleri açılmış, yine aynı yıl kadın sorunları konusunda ulusal mekanizma olarak görev yapacak olan Kadının Statüsü ve Sorunları Genel Müdürlüğü (KSSGM), 3670 sayılı kanunla Çalışma ve Sosyal Güvenlik Bakanlığına bağlı olarak kurulmuştur (Sipahi ve Özsoy 2016: 79-80). 2001 yılındaki yeni Medeni Kanun ile aile reisi kavramı kaldırılarak kanun önünde eşlerin statüleri eşitlenmiş; 2003 İş Kanunu ile ilk kez, iş yerindeki cinsel istismarın engellenmesine yönelik hükümler kanuna eklenmiştir (Dedeoğlu ve Elveren 2012: 34). 2004 yılında cinsiyet eşitliğini sağlama görevinin devlete ait olduğu anayasada belirtilmiştir (Dedeoğlu 2009: 48-49). 2006 yılındaki "Çocuk ve Kadınlara Yönelik Şiddet Hareketleriyle Töre ve Namus Cinayetlerinin Önlenmesi İçin Alınacak Tedbirler” konulu genelge ile kent planlaması, sokak aydınlatması, şiddetle mücadele için güvenliği artırılması gibi alanlarda yerel yönetimlere sorumluluk verilmiştir. 2010 yılındaki "Kadın İstihdamının Artırılması ve Fırsat Eşitliğinin Sağlanması” konulu Başbakanlık Genelgesi ise, kadınların sosyo-ekonomik konumlarının güçlendirilmesi, toplumsal yaşamda kadın erkek eşitliğinin gerçekleştirilmesi, kadın istihdamının artırılması ve eşit işe eşit ücret imkânının sağlanması amacıyla alınacak tedbirleri düzenlemektedir (Tekinbaş 2015: 21-22).

2011 yılında Avrupa Konseyi Bakanlar Komitesince kabul edilen "Kadına Yönelik Şiddet ve Aile İçi Şiddetin Önlenmesi ve Bunlarla Mücadeleye İlişkin Avrupa Konseyi Sözleşmesi imzalanarak kadına karşı şiddetin türleri tanımlanmış ve bu suçlara karşı yaptırımlar öngörülmüsstür (TC. Kadının Statüsü Genel Müdürlüğü 2012: 2). Yine, 2012 yılında çıarılan 6284 sayılı Ailenin Korunması ve Kadına Karşı Şiddetin Önlenmesi Kanunu ile şiddete uğrayan veya şiddete uğrama tehlikesi bulunan kadınların ve çocukların korunması hedeflenmiştir (Sipahi ve Özsoy 2016: 104).

\section{Azerbaycan}

1991 yılında bağımsızlığını kazanan Azerbaycan hızlı bir kalkınma sürecine girmiştir. 2016 yll itibari ile 9.696 .800 olan nüfusun $\% 53$,2'si şehirlerde $\% 46,8$ 'i köylerde yaşamaktadır. Ülke nüfusunun $\% 50,3$ 'ü kadınlardan oluşmaktadır (Azərbaycan Respublikasının Dövlət Statistika Komitəsi 2015: 9).

Bağımsızlığın ardından, Azerbaycan kadın sorunlarına yönelik ulusal ve uluslararası alanda sözleşme ve anlaşmalara taraf olmaya başlamıştır. 1992 yılında Kadınların Siyasi Haklarına dair BM sözleşmesi, 1995 yılında BM Kadınlara 
Karşı Her Türlü Ayrımcıllğın Önlenmesine Dair Sözleşme (CEDAW) imzalanmış ve 2001 yılında İhtiyari Protokol kabul edilmiştir (Aliyeva Guriyeva 2011). 1998 yılında, şimdiki adı ile Azerbaycan Cumhuriyeti Aile, Kadın ve Çocuk Sorunları Devlet Komitesi kurulurken, Bakanlar Kurulu da, tüm devlet kurumlarında cinsiyet eşitliğinin sağlanması amacı ile 2000-2005 ve 2007-2011 yıllarını kapsayan Ulusal Eylem Planlarını kabul etmiştir. 2010 yılında Aile İçi Şiddetin Önlenmesi Hakkında kanun kabul edilerek şiddetle mücadelede özel alana yönelik düzenlemelere gidilmiştir (UN 2013: 44). Yine aynı yıl, "Ulusal Cinsiyet Politikasının Uygulanması" üzerine bir Kararname cumhurbaşkanınca imzalanmış ve bu sayede tüm devlet yapılarında kadın ve erkeğin eşit temsili öngörülmüştür. Aynı kararnamede mülteci kadınlar ve yerinden edilmiş kadınlar için de düzenlemeler getirilmiştir (www.mfa.gov. az/en/content/111 2013). Resmi verilere göre nüfusunun \%12'si yerinden edilmiş ve mültecilerden oluşan Azerbaycan bu yönüyle diğer Türk Cumhuriyetlerinden ayrı ele alınmaktadır (UNFPA 2015: 21). Zira 1999 verilerine göre, yerinden edilmiş ve mültecilerin $\% 55^{\prime}$ inin kadın ve çocuklardan oluştuğu düşünüldüğünde, kadın sorunlarının iki perspektif üzerinden ele alınması gerekmektedir (Tohidi 1999: 66). Yapılan araştırmalara göre, mülteci kadınların \%73'ünün fiziksel sağlıklarının bozulduğu tahmin edilmektedir. Yine, mülteci kadınların \%93'ü, yerinden edilmiş kadınların ise tamamı, yaşamış oldukları psikolojik sorunların ana nedeni olarak çatışmaları göstermektedir (Mandl 2011: 10, UNDP 2007: 64). Bu kapsamda yaşamış oldukları sorunlar göz önüne alınarak yerinden edilmiş ve mülteci kadınlar için özel önlem ve hizmetlerin uygulanması gerektiği ifade edilmelidir.

\section{Kırgizistan}

Orta Asya ülkeleri içerisinde bağımsızlık sonrası siyasi ve ekonomik başta olmak üzere önemli sorunların ortaya çıktığı ülkelerden olan Kırgızistan, \%34,5'lik kentleşme oranı göz önüne alındığında tarım toplumu özelliği göstermektedir (ILO 2015: 13). Yaşanan siyasi ve ekonomik krizler bir yandan ülkenin gelişmesi ve kalkınmasını zorlaştıııken, öteki yandan siyasi, ekonomik ve toplumsal yaşamda kadınların güçlenmesini engelleyerek kadın ve erkek arasındaki eşitsizliği artırmıştır.

Ülkede, 1996 yılında kadın sorunlarına etkin çözümler getirebilmek amacıyla kadın ve aile konularında ulusal bir Komisyon kurulmuştur. Ulusal Konsey'in amacı cinsiyet, aile ve kadın sorunları hakkında hükümet politikasının ko- 
ordinasyonunu sağlamaktır (Toktayim ve Aitkulova 2007: 7). 1997 yılında, Birleşmiş Milletler Kadınlara Karşı Her Türlü Ayrımcılığın Önlenmesi Sözleşmesi’ni (CEDAW) yürürlüğe koyan Kırgızistan, 2000 yılında da Binyıl Kalkınma Hedeflerini gerçekleştirmeyi taahhüt etmiştir. 2003 yılında Aile İçi Şiddetten Sosyo-Hukuki Koruma Kanunu kabul edilerek aile içi şiddetle mücadelede yasal bir adım atılmıştır (www.hrw.org/legacy/pub/2008/eca/Kyrgyzstan_domestic_-violence220908.pdf Erişim Tarihi: 05.10.2016). Siyasi alanda kadın görünürlüğünü artırmak amacıyla, 2011 yılından bu yana seçimlerde \%30 kota uygulaması bulunmaktadır (Seçim Kanunu, 60, 61). 2012 yılında 2020 Yılına Kadar Cinsiyet Eşitliğinin Başarılması için "ekonomide kadın", "kız çocukları ve kadınlar için eğitim”, "adalete erişim” ve "siyasal eşitlik" başlıklarını önceleyen Ulusal Strateji Belgesi kabul edilmiştir. Yine, Kırgızistan Cumhurbaşkanının inisiyatifiyle geliştirilen Kırgız Cumhuriyeti 2013-2017 Sürdürülebilir Kalkınma Ulusal Stratejisi, aile politikası ve cinsiyet gelişimi başlıklarında ayrı bir bölüm içermektedir (www.National+and+International-+Obligations+of+the+Kyrgyz+Republic+in+Achieving+Gender+Equality, 2015).

Bütün düzenlemelere rağmen Kırgızistan'da gelenek ve görenekler kadınları etkilemeye devam etmektedir. Özellikle 2000 yılından itibaren ülkede erken evliliklerin yaygın biçimde olduğu görülmektedir (OECD 2014: 2, ILO 2015: 14). Erken evliliklerle birlikte, 2006 yılından sonra 18-19 yaş aralığında kadınların doğum oranı da gözle görülür bir biçimde artmıştır. Buna göre, 2007 yılında söz konusu yaş aralığında her 1000 kadından 61,6'sı doğum yaparken bu oran 2011 yllında binde 91,9 olarak gerçekleşmiştir (National Statistical Committee of the Kyrgyz Republic 2012: 51). Geleneklerin sürdürüldüğü bir başka sorun ise, "gelin kaçırma" adı verilen evliliklerdir. Yapılan araştırmalarda ülkede, yılda 13-15 bin arası kadın kaçırma vakasının yaşandığı belirtilmektedir (Myrzabekova 2013). Yine, STK ve Kadın Destek Merkezi verilerine göre, günde en az $32 \mathrm{kız}$ veya kadının kaçırıldığına dikkat çekilmektedir (U.S. Department of State 2015: 24).

Ülkede yaşanan ekonomik bunalım, kadınların karşı karşıya kaldığı bir başka sorundur. Bu sorun, yoksulluk-ücretsiz aile işçiliği veya ücret adaletsizliği-enformel sektör sarmalında daha da derinleşmektedir. Buna göre ülkede, 2010 yılı yoksul kadın oranı 32,7; 2011 yılında \%36,1 ve 2012 yılında 37,2 olmuştur (National Statistical Committee of the Kyrgyz Republic 2012: 110; 
National Statistical Committee of the Kyrgyz Republic 2013: 112). Kadın yoksulluğunun artmasındaki önemli faktör olan tarım sektörünün ekonomideki ağırlı̆̆ı, kadınları "ücretsiz aile işçiliğine" yöneltmektedir (ILO 2013). Yine, ülkede çalışan kadınların \%80,6'sı kayıt dışı istihdam edilmekte (ILO 2015) ve çalışan kadınlar erkeklerin elde ettiği gelirin yalnızca \%63'ünü elde etmektedir (National Statistics Committee 2014, European Bank 2015’den).

\section{Kazakistan}

Dünyada en büyük yüz ölçümüne sahip 10 ülkeden biri olan Kazakistan'da kentsel nüfus oranı \%50,7 iken, 2015 yılı kadın nüfus oranı \%51,71'dir. Ülkede Sovyet sonrası dönemde, kadınların sosyo-ekonomik koşulları geçiş döneminin vermiş olduğu dalgalanma ile birlikte negatif bir seyir izlese de, sonrasında CEDAW (1998 yılında), Avrupa İnsan Hakları Sözleşmesi gibi uluslararası belgelerin imzalanmış olması, cinsiyet eşitliğini sağlamaya yönelik adımlar olması açısından önemli gelişmelerdir. Uluslararası sözleşme ve anlaşmaların yanı sıra, Kazakistan ulusal sınırlar içerisinde de kadınlara yönelik olarak bir takım düzenlemeler yapmıştır. 1998 yılında cinsiyet eşitliği stratejisini gerçekleştirmede birincil görevli olan Kadın Sorunları, Aile ve Nüfus Politikası Ulusal Komisyonu (National Commission for Women's Affairs, Family and Demographic Policy) kurulmuştur. 2005 yilında cumhurbaşkanı tarafından Cinsiyet Eşitliği Stratejisi onaylanmış, akabinde stratejinin uygulanması amacıyla 2006-2008, 2009-2011, 2012-2016 yıllarını kapsayan eylem planları kabul edilmiştir. 2009 yılında Eşit Haklar Yasası olarak bilinen, Kadın ve Erkeklerin Eşit Hak ve Fırsatlarının Devlet Garantisi Yasası kabul edilmiştir. Yine aynı yıl, Aile İçi Şiddetin Önlenmesi Hakkında Kanun kabul edilmiştir. Kanun, yerel programlar ve yerel otoritelerin geliştirilmesini sağlamış, şiddet mağdurlarına sosyal hizmet, hukuki ve psikolojik yardım desteği öngörmüştür (Asian Development Bank 2013: 6- 28). 2014 yılında bahsi geçen yasada yapılan değişiklikle, sığınma evi olmayan her bölgeye sığınak yapılması kararlaştırılmıştır (U.S. Department of State 2015: 28). Yapılan düzenlemelere karşın ülkede şiddetin ve ataerkil düşünce kalıplarının yaygınlığı dikkat çekicidir. Buna göre yasalarda tecavüz şikâyete dayalı bir suçtur ve Kırgızistan'da görülen gelin kaçırma âdeti Kazakistan'ın özellikle güney kesimlerinde devam eden önemli bir sorundur (OECD 2014: 3-4).

Çalışma yaşamına bakıldığında, ülkedeki kadınların eğitim, sağlık gibi belirli mesleklerde yoğunlaşması nedeniyle sektörel bir ayrımcılığın oluştuğu göz- 
lemlenmektedir (Kapysheva 2014: 2). Bunun yanında, kadınların yıllık kazançlarının erkeklerin kazançlarının en fazla \%71'i olması da, çalışma yaşamındaki eşitsizliğin bir göstergesidir (Asian Development Bank(b) 2013: 11). Karar alma ve uygulama mekanizmalarında kadın oranı ise, diğer Türk Cumhuriyetleriyle kıyaslandığında nispeten daha yüksektir. Buna göre, 2016 yılı itibari ile kadın parlamenter oranı \%27,1 ile Türk Cumhuriyetlerindeki en yüksek orandır.

\section{Türkmenistan}

Doksanlı yılların başında doğalgaz üretiminde dünyada dördüncü sırada olan Türkmenistan (Geybullayev ve Kurubaş 2002: 26) bu zenginliğini ekonominin başka dallarına yansıtamadığından, ekonomisi doğalgaza ve tarıma bağımlı şekilde sürdürülmektedir.

Bağımsızlığın ardından yaşanan işsizlik ve yoksulluk, bir yandan sosyal ve ekonomik yaşamda kadınlar üzerinde negatif bir etkiye neden olurken, öbür taraftan geleneksel değerlerin sürdürülmesi zihniyet değişiminin yaşanmasını engellemiştir. Türkmen toplumunda, toplum ve ailede kadına yönelik ataerkil tutum ve kalıplaşmış yargıların kadının rol ve sorumlukları üzerindeki etkisi devam ederken, bir yandan da uluslararası sözleşmelere taraf olunarak toplumsal alanda cinsiyet eşitsizliğinin ortadan kaldırılması amaçlanmıştır. Bu bağlamda, kadın erkek eşitliğini sağlamak amacıyla 1996 yılında CEDAW ve ILO Sözleşmesi imzalanmıştır. 1997 yılında UNDP desteği ile açlan Ulusal Büro ile toplumsal hayatın her kademesinde kadınların güçlendirilmesi amaçlanmıştır (Statıstıcal Commıssıon and Economıc Commıssıon for Europe 2000: 3). 2007 yılında Cinsiyet Eşitliği için Devlet Teminatı Yasası kabul edilmiş ancak, bu yasa çerçevesinde herhangi bir uygulama geliştirilememiştir (The Norwegian Helsinki Committee 2013: 9). Kadın erkek eşitliğini yasalarında vurgulayan Türkmenistan'da devlet, hak ihlallerine karşı garantör durumda olmasına karşın uygulamada kadın-erkek eşitliğinin sağlanamadığı görülmektedir (The Norwegian Helsinki Committee 2013: 9).

Türkmenistan'da kadına karşı şiddete dair resmi bir veri bulunmamasına rağmen, aile içi şiddetin yaygın olduğu bilinmektedir (Submission to the United Nations Committee on the Elimination of Discrimination against Women 2012: 5). Şiddetle mücadelede en önemli işleve sahip mekanizmalardan olan sığınma evleri ise yeterli değildir. Buna göre ülkede, yalnızca bir STK tarafın- 
dan işletilen tek bir Kadın Sığınma Merkezi bulunmaktadır (U.S. Department of State 2015: 18).

\section{Özbekistan}

Orta Asya’da Çin ve Avrupa kavşağında konumlanan Özbekistan, genç nüfus yapısı ile dikkat çekerken bağımsızlığın ardından siyasi ve ekonomik istikrarsızlıkla karşı karşıya kalmıştır. Resmi verilerin kısıtlı olduğu ülkede yasal eşitliğe karşın, katı toplumsal kalıpların olması cinsiyet ayrımcllığının ve erkek egemen anlayışın sürdürülmesine neden olmaktadır (İbrahim 2013: 50).

1991 yılında kurulan Kadın Komisyonu hükümetin kadın politikalarından sorumlu olan temel kurumdur (İbrahim 2013: 52). 1992 yilında CEDAW'1 imzalayan Özbekistan, bu tarihten sonra uluslararası alanda Pekin Deklerasyonu ve Eylem Planı (1995), Eşit Değerde İş İçin Erkek ve Kadın İşçiler Arasında Ücret Eşitliği Sözleşmesi (1997), Kadınların Siyasi Haklarına Dair Sözleşme (1999) gibi birçok uluslararası sözleşmeye dâhil olmuştur (Egamberdieva 2016: 48). 1995 yllında kabul edilen "Devlet ve Kamu Binalarında Kadınların Rolünü Artırma Tedbirleri Hakkında Cumhurbaşkanlığı Kararnamesi” ile karar mekanizmalarında kadın görünürlüğü artırılmaya çalışılmıştır. 1998 yılında kabul edilen Aile Kanunu da, evlilik birliği içerisinde kadın ve erkeklerin kişisel ve mülki eşitliğini vurgulamakta; çocuk bakımı, eğitim vb. ailevi sorumluluklarda kadın ve erkeğe yükümlülükler getirmektedir (Yussupov 2016: 13). Ülkede işgücü piyasasında da ayrımcilığa maruz kalan kadınlar, eğitim, kültür gibi belirli meslek dallarında yoğunlaşmakta ve erkeklerin kazandığı ücretten \%40 daha az gelir elde etmektedir.

Tüm bu olumsuzluklara rağmen Binyıl Kalkınma Hedefleri doğrultusunda Özbekistan eğitimde, istihdamda ve siyasi karar alma mekanizmalarında cinsiyet eşitsizliğini ortadan kaldırmayı hedeflemiştir. Bu kapsamda;

İlk ve orta öğretimde cinsiyet eşitsizliği ortadan kaldırıllıken yükseköğretimde eşitsizlik sürmektedir. Buna göre 2013-2014 yılında yükseköğretimde erkek oranı \%62,7 iken kadınlarda bu oran \%37,3’tür.

2000 yilında \%44 olan kadın istihdam oranı 2013 yılında \%45,7 olmuştur.

Kota sistemi sayesinde kamuda çalışan kadın oranı önemli ölçüde artırılmıştır. Buna göre, yürütme gücündeki kadın oranı 2005 yılında \%3,4'ten 2013 yılın- 
da \%16'ya yükselmiştir (Millennium Development Goals Report in Uzbekistan, 2015: 37-43)

Bütün gelişmelere karşın, uluslararası raporlarda Özbekistan siyasi, ekonomik, sosyal alanlarda diğer Orta Asya Türk Cumhuriyetlerinin gerisinde kalmaya devam etmektedir.

\section{İnsani Gelişim Raporu ve Küresel Cinsiyet Eşitsizliği Raporlarında Türk Cumhuriyetleri}

İnsani Gelişim Raporu

Birleşmiş Milletler Kalkınma Programı (UNDP) tarafından 1990 yılından bu yana her yıl hazırlanan rapor, belirli verilerle ülkeleri insani gelişmişlik düzeyine göre sıralamaktadır. Rapor içerisinde yer alan insani gelişim endeksi sağlık, eğitim ve gelir gibi üç temel veriyi baz alarak hesaplanmaktadır (SDE 2015: 5). Her rapor, bir tema üzerine odaklanarak yayımlanmaktadır. Buna göre, çalışmada ele alınacak olan 2015 yılı İnsani Gelişme Raporu, "çalışma” kavramına odaklanmaktadır.

Tablo 1. Human Development Report 2015

Ülkeler

Kategoriler

Türkiye Azerbaycan Kazakistan Kırgızistan Türkmenistan Özbekistan

\begin{tabular}{|c|c|c|c|c|c|c|}
\hline $\begin{array}{l}\text { İnsani Gelişim } \\
\text { Kategorisi } \\
\text { (188 ülke) }\end{array}$ & 72 & 78 & 56 & 120 & 109 & 114 \\
\hline \multicolumn{7}{|l|}{$\begin{array}{l}\text { Cinsiyet Eşit- } \\
\text { sizliği Endeksi }\end{array}$} \\
\hline & 71 & 59 & 52 & 67 & - & - \\
\hline \multirow{3}{*}{$\begin{array}{l}\text { Doğumdan } \\
\text { Beklenen } \\
\text { Yaşam Süresi, } \\
\text { Erkek-Kadın }\end{array}$} & & & & & & \\
\hline & 72,0 & 67,7 & 64,6 & 66,6 & 64,1 & 65,0 \\
\hline & 78,5 & 74 & 74,1 & 74,6 & 69,9 & 71,8 \\
\hline $\begin{array}{l}\text { Ergen Doğum } \\
\text { Oranı (15-19 } \\
\text { yaş arası } 1000 \\
\text { kadın) }\end{array}$ & 30,9 & 40 & 29,9 & 29,3 & 18 & 38,8 \\
\hline
\end{tabular}




\begin{tabular}{|c|c|c|c|c|c|c|}
\hline $\begin{array}{l}\text { Anne Ölüm } \\
\text { Oran1 (100 bin } \\
\text { canlı doğum- } \\
\text { da) }\end{array}$ & 20 & 26 & 26 & 75 & 61 & 36 \\
\hline $\begin{array}{l}\text { Yetişkinlerde } \\
\text { En az Ortaöğ- } \\
\text { renim Görme } \\
\text { Oranı Er- } \\
\text { kek-Kadın }\end{array}$ & $\begin{array}{c}\% 60 \\
\% 39,0\end{array}$ & $\begin{array}{l}\% 97,4 \\
\% 93,7\end{array}$ & $\begin{array}{c}\% 98,8 \\
\% 95,3\end{array}$ & $\begin{array}{l}\% 96,8 \\
\% 94,5\end{array}$ & - & - \\
\hline $\begin{array}{l}\text { Yı1lık Kişi } \\
\text { Başı GSMH } \\
\text { Erkek- Kadın } \\
\text { (2014 Y111) }\end{array}$ & $27,645 \$$ & $22,814 \$$ & $26,746 \$$ & $\begin{array}{l}3,992 \$ \\
2,122 \$\end{array}$ & $\begin{array}{r}17,552 \\
8,752\end{array}$ & 7,342 \\
\hline $\begin{array}{l}\text { İşgücüne } \\
\text { Katılım Oranı } \\
(15+), \text { Er- } \\
\text { kek-Kadın }\end{array}$ & $\begin{array}{l}\% 70,8 \\
\% 29,4\end{array}$ & $\begin{array}{l}\% 69,6 \\
\% 62,9\end{array}$ & $\begin{array}{l}\% 77,9 \\
\% 67,7\end{array}$ & $\begin{array}{l}\% 79,5 \\
\% 56,0\end{array}$ & $\begin{array}{l}76,9 \\
46,9\end{array}$ & $\begin{array}{r}75,6 \\
48,1\end{array}$ \\
\hline $\begin{array}{l}\text { Parlamentoda- } \\
\text { ki Kadın Oranı }\end{array}$ & $\% 14,9$ & $\% 15,6$ & $\% 20,1$ & $\% 23,3$ & 25,8 & 16,4 \\
\hline
\end{tabular}

2015 yılındaki İnsani Gelişim Raporu'nun ele alındığı Tablo 1 incelendiğinde; insani gelişim kategorisinde Kazakistan'ın diğer beş ülkeden daha başarılı olduğu gözlemlenmektedir.' Buna göre, Kazakistan’da cinsiyet eşitsizliği nispeten daha az oranda görülürken, yetişkin kadınlarda ortaöğretim düzeyi, kişi başına GSMH oranı ve işgücüne katılım oranı da, diğer beş ülkeden daha yüksek oranda bir gelişim göstermiştir. Kazakistan'ın aksine, cinsiyet eşitsizliğinin en fazla görüldüğü ülke ise Türkiye olmuştur. ${ }^{2}$ (Yetişkin kadınlar içerisinde ortaöğrenim gören kadın oranının en düşük olduğu ülke de Türkiye'dir.) Raporda Türkiye, parlamentodaki kadın oranı ve işgücüne katılım oranında da diğer beş ülkenin gerisinde yer almaktadır. Bununla birlikte, Binyıl Kalkınma Hedeflerinden biri olan anne ölümlerinin azaltılması konusunda Türkiye'de önemli bir gelişme kaydedilmiştir. Diğer beş ülke ile kıyaslandığında, anne ölümlerinin en az gerçekleştiği ülke Türkiye'dir. Bu kategoride Kırgızistan ise diğer ülkelerden daha kötü durumdadır. Buna göre ülkede 100 bin canlı doğumda 75 kadın hayatını kaybetmektedir. Böylece Kırgızistan kişi başına yıllık GSMH oranının en düşük ve anne ölüm oranının en fazla olduğu ülke olmuştur. Türkmenistan, parlamentodaki kadın temsilinde diğer beş ülkeden en iyi durumda olanıdır. Buna göre ülkede parlamentodaki kadın oranı 
\%25,8'dir. Türkiye diğer beşülke ile kıyaslandığında, anne ölümlerinin en az yaşandığı ve kadınların yaşam sürelerinin en fazla olduğu ülke olmuştur. Azerbaycan, ergen doğum oranının en fazla olduğu ülke olmuştur. Genel olarak değerlendirildiğinde ise Kazakistan Türk Cumhuriyetleri içerisinde kadınlar için eşitlik, eğitim, istihdam ve GSMH göstergelerinde en iyi koşulların olduğu ülke olmuştur.

Küresel Cinsiyet Eşitsizliği Endeksi

Cinsiyet Eşitsizliği Endeksi 2006 yılından bu yana Dünya Ekonomik Forumu tarafından yayımlanan ve ülkelerin toplumsal cinsiyet eksenindeki eşitsizliklerini ve ülkelerin bu konudaki gelişimlerini takip eden endekstir. Forum, ülkeleri, ekonomiye katılım ve firsat eşitliği, eğitime erişim, să̆llk ve yaşam süresi ile politik arenadaki gücüne göre dört faktörü değerlendirerek raporunu oluşturmaktadır.

Tablo 2. The Global Gender Gap Report 2015

\begin{tabular}{lcccc}
\hline \multirow{2}{*}{$\mathbf{1 4 5}$ ülke İçerisindeki Sıralama } & \multicolumn{4}{c}{ Ülkeler } \\
\cline { 2 - 5 } & Türkiye & Azerbaycan & Kazakistan & Kırgızistan \\
\hline Cinsiyet Eşitsizliği & 130 & 96 & 47 & 76 \\
\hline Eŭitime Ulaşım & 105 & 90 & 28 & 81 \\
\hline Okuma Yazma Oranı & 105 & 55 & 48 & 60 \\
\hline Sağlık ve Hayatta Kalma & 1 & 139 & 1 & 79 \\
\hline Ekonomik Katılım ve Fırsat Eşitliği & 131 & 54 & 36 & 80 \\
\hline Tahmini Gelir Sıralaması & 130 & 124 & 89 & 105 \\
\hline İşgücüne Katılım Oranı & 131 & 20 & 24 & 94 \\
\hline Siyasi Güçlenme & 105 & 129 & 78 & 76 \\
\hline Kadın Parlamenter Oranı & 86 & 99 & 49 & 64 \\
\hline Kanun Yapıcılar, Üst Düzey Yetkili & 109 & 56 & 26 & 77 \\
Ve Yöneticiler & & & & \\
\hline
\end{tabular}

Tablo 2 incelendiğinde diğer üç ülke ile kıyaslandığında, cinsiyet eşitsizliğinin en fazla olduğu ülke Türkiye olmuştur. Buna göre, Türkiye eğitime ulaşım, okuma yazma oranı, ekonomik katılım ve fırsat eşitliği, tahmini gelir sıralaması, işgücüne katılım oranı, siyasi katılım, kanun yapıcılar- üst düzey yetkili ve yöneticiler kategorilerinde diğer üç ülkenin gerisinde kalmıştır. ${ }^{3}$ 
Azerbaycan raporda, sağlık koşullarının en kötü olduğu ülke olurken, siyasi güçlenmenin de en zayıf olduğu ülke olmuştur. Siyasi güçlenmede en güçlü olan ülke ise Kırgızistan'dır. Kuşkusuz bu durumun temel nedeni 2011 yılından bu yana seçimlerde \%30 kota uygulamasının getirilmesidir. Kazakistan ise, Türkiye ile birlikte sağlık ve hayatta kalma koşullarının en iyi olduğu ülke olurken, ülkede kanun yapıcı- üst düzey yetkili ve yönetici kadın oranı, kadın parlamenter oranı, okuma yazma oranı diğer ülkelerden daha yüksektir. Yine Kazakistan, tahmini gelir sıralaması, ekonomik katılım ve firsat eşitliği, eğitime ulaşım gibi verilerde de diğer ülkelerden daha yüksek gelişmişlik seviyesine sahiptir. Buna göre 2015 ylı Küresel Cinsiyet Eşitsizliği Raporunda Kazakistan, diğer üç ülke ile kıyaslandığında cinsiyet eşitsizliğinin en az görüldüğ̈̈ ülke olmuştur.

Tablo 1 ve Tablo 2 birlikte değerlendirildiğinde, Kazakistan'ın insani gelişim ve cinsiyet eşitsizliğinin ortadan kaldırılması konularında diğer Türk Cumhuriyetlerinden daha başarılı bir konumda olduğu görülmektedir. Cinsiyet eşitsizliğinin ortadan kaldırılarak kadınların siyasi, ekonomik, toplumsal göstergelerde görünürlüklerinin artmasında kadınların eğitim imkânlarına ulaşması büyük önem taşımaktadır. Buna göre, Kazakistan'ın kadın okuryazar oranı ve eğitime ulaşım oranı gibi kalemlerde diğer ülkelerden daha yüksek bir performans göstermiş olması, söz konusu ülkede kadınların istihdam, ekonomik katılım ve fırsat eşitliği, kadınların gelir seviyeleri gibi göstergelerde de diğer ülkelerden daha başarılı olmasını sağlamışıı. Bunun yanında kadın okuryazarlığının her iki raporda da en düşük olduğu ülke olan Türkiye'de, kadınların karar alma mekanizmalarında, istihdama katılımında ve cinsiyet eşitsizliğindeki düşük oranları dikkat çekmektedir. Buna göre, Türkiye’nin Batı ile olan yakın ilişkisi, Avrupa Birliğine adaylı̆̆ı ve uluslararası alandaki nispeten güçlü konumunun avantajlarını kadınların eğitim, istihdam, siyaset gibi önemli verilerdeki oranlarına yansıtamadığı görülmektedir. Bahsi geçen diğer ülkelerin bağımsızlıklarını yeni kazanmış oldukları, bir takım gelenek ve göreneklerin kadın yaşamını Türkiye’den daha fazla etkilediği düşünüldügünde, cinsiyet eşitsizliğinin ortadan kaldırılmasını sağlayan göstergelerde daha başarılı oldukları anlaşılmaktadır. 


\section{Sonuç}

1980'li yıllarla birlikte kadın sorunlarına olan ilginin artması ve uluslararası alandaki gelişmelerin ülkeler nezdinde de karşılık bulmasıyla, kadınların toplumsal konumlarının iyileştirilmesi çabaları artmış ve cinsiyet eşitliğinin sağlanması özellikle gelişmekte olan ülkelerin öncelikli konularından biri haline gelmiştir. Kadını kamusal alandan soyutlayan ve kadın sorunlarını görmezden gelen yaklaşımların ülkelerin gelişmesi ve kalkınması yönündeki engellerin başında geldiğinin anlaşılması ile birlikte ülkeler ekonomik, siyasi ve toplumsal yaşamda kadınların görünürlüklerini artırmayı gerek hukuksal, gerekse toplumsal alanda yapılan uygulamalarla gerçekleştirmeye çalışmışlardır. Kadını ikincilleştiren bir takım geleneklerin sürdürüldüğü ve ataerkil toplum yapısının hâkim olduğu ülkelerde kadın sorunlarına olan özel ilginin nedeni de bu olmuştur.

Gelişmekte olan ülkeler kategorisinde olan Azerbaycan, Türkiye, Kazakistan, Kırgızistan, Türkmenistan ve Özbekistan'da, kadın-erkek arasında cinsiyet eşitliğinin sağlanması ve eğitim, sağlık, istihdam, yönetim gibi temel göstergelerde kadın görünürlüğünün artırılması yönünde hukuksal hiçbir engel bulunmamasına karşın, uygulamadaki boşluk ve kurumsal eksikliklerden dolayı söz konusu göstergelerdeki kadın oranlarının oldukça düşük olduğu gözlemlenmektedir. Türkiye haricindeki diğer beş ülkenin de, bağımsızlıklarını 90’lı yıllarda kazandıkları göz önüne alındığında, bu ülkelerdeki ekonomik ve siyasi krizlerin kadınların sosyo-ekonomik koşullarını etkilemesi kaçınılmaz olmuş; Sovyet dönemi ile kıyaslandığında, kadın istihdamı ve karar mekanizmalarındaki kadın oranları düşüş göstermiştir. Ancak Türkmenistan ve Özbekistan ayrı tutulduğunda, diğer ülkelerin cinsiyet eşitliğini sağlamada Türkiye'den daha başarılı olması dikkat çekicidir. Sovyet dönemi eğitim ve istihdam politikalarının bu başarı da payı olsa da, ortak kültür, tarih ve gelenekleri paylaşan Türk Cumhuriyetleri arasındaki cinsiyet eşitsizliği makasının daraltılması bir zorunluluk olmaktadır. Zira, gerek İnsani Gelişim Raporu, gerekse Küresel Cinsiyet Eşitsizliği Raporu'nda, diğer beş ülkeye göre daha başarılı bir profil çizen Kazakistan'la en başarısız ülkeler arasındaki fark oldukça büyüktür.

Kısaca ifade etmek gerekirse, hukuksal alanda cinsiyet eşitliğinin sağlanmasında ülkelerin hiçbirinde engel bulunmayışı, Orta Asya, Kafkasya ve Türkiye'de temel göstergelerde kadın görünürlügünün gelişmiş ülkeler seviyesine 
çıkartılmasında, işbirliği ve uygulamaya yönelik adımların gerekliliğine işaret etmektedir.

Çalısma, Türk Cumhuriyetlerindeki kadın haklarının gelişiminin ve kadınların temel göstergelerdeki oranlarının öneminden yola çıkarak Sovyetlerin dağılması sonrası bağımsızlığını kazanan ülkelerdeki kadın sorunsalı ile Türkiye'de kadın hakları ve gelişimini karşılaştırmalı bir biçimde ele almaktadır. Sovyetlerden kalan kurum ve kuruluşların hızlı tasfiyesi, çöken ekonomiler, artan yoksulluk ve özellikle günden güne şiddeti artan etnik temelli bölgesel sorunlar kadınların Sovyet döneminde sahip olduğu birçok hakkı kaybetmesine ve "kadın sorunlarının" bu ülkelerde ihmal edilmesine ya da yüzeysel şekilde ele alınmasına yol açmıştır. Bu nedenle, örneğin Orta Asyảnın kapalı kutusu olarak kabul edebileceğimiz Özbekistan'daki (Türkmenistan da bu şekilde tanımlanabilir) ve Türkmenistan'daki kadın görünürlüğü hakkında sınırlı sayıda çalışma olması ve yine söz konusu ülkelerin temel göstergelerindeki kadın oranları ile ilgili verilerin azlığı dikkat çekicidir. Çalışma ile birlikte, söz konusu ülkelerde kadın haklarının gelişimi ve çeşitli göstergelerdeki kadın oranları bir bütün olarak ele alınmaktadır. Özellikle çalışmanın ikinci bölümünde çeşitli parametreler dikkate alınarak oluşturulan İnsani Gelişme Raporu ve Küresel Cinsiyet Eşitsizliği Endeksi Raporu'ndaki kadınlarla ilgili veriler derlenerek söz konusu ülkelerdeki kadın oranları karşılaştırılmış ve sonuçlar yorumlanmıştır. Çalışma, tarihi ve kültürel yakınlıklarına karşın Türkiye, Azerbaycan, Kazakistan, Kırgızistan, Türkmenistan ve Özbekistan arasında kadın hakları, kadın sorunları, kadınların mevcut konumları ve temel göstergelerdeki kadın görünürlüğü arasında önemli farklılıklar olduğunu göstermesi açısından önemlidir. Türk Cumhuriyetlerindeki kadın hakları, kadın sorunları gibi kadınlara yönelik çalışmalar ülkeler nezdinde daha önce kimi araştırmaların konusu olmuş olsa da, bu çalışma ile birlikte bir bütün olarak Türk devletleri ele alınmışır. Buna göre, uluslararası raporlardaki kadın verileri karşılaştırılmış ve bahsi geçen ülkelerdeki kadınların sahip olduğu mevcut haklar ve sorunlar araştırılarak ülkelerin kadın hakları konusundaki durumları kıyas yoluyla değerlendirilmiştir. 


\section{Açıklamalar}

1. Raporda Türkiye, Azerbaycan, Kazakistan Yüksek insani gelişme grubunda yer alırken Kırgızistan, Türkmenistan ve Özbekistan orta insani gelişme kategorisinde yer almaktadırlar.

2. Bu kategoride Türkmenistan ve Özbekistan bulunmamaktadır.

3. Toplumsal Cinsiyet Eşitsizliği sonrasında ülkelerin yapmış olduğu parlamento seçimleri baz alındığında Türkiye parlamentodaki kadın oranında da diğer ülkeler içerisinde son sırada gelmektedir. Buna göre 2016 yılı itibari ile Azerbaycan parlamentosundaki kadın oranı \%16,8 iken Türkiye'de \%14,9'dur.

\section{Kaynaklar}

ADB (2016). Basic Statistic 2016 Economic Research and Regional Cooperation Department. April.

ADB (2013a). Kazakhstan Country Gender Assessment. Philippines.

ADB (2013b). Gender Equality and the Labor Market: Cambodia, Kazakhstan, and the Philippines. Philippines.

Akçiçek, Arda (2015). 2014 Insani Gelişme Endeksi ve Türkiye’nin İnsani Gelişme Performansı. Ankara: Stratejik Düşünce Enstitüsü Raporu.

Azərbaycan Respublikasının Dövlət Statistika Komitəsi (2015). Azərbaycanda Səhiyyz, Sosial Taminat vo Mənzil Şəraiti. Bakı.

Bassiuoni, Sarah. Briefing Note on the Situation of Women in Central Asia. UN Working Paper. http://www.unesco.org/new/en/unesco/themes/genderequality/ (Erişim Tarihi: 10.10.2016).

Blackburn, Rebecca Anne (2011). Women of Kyrgyzstan and Tajıkıstan: Historical Legacies Impactıng Contemporary Involvement. Master Thesis of Arts in Russian: University of Illinois at Urbana-Champaign.

Dedeoğlu, Saniye (2009). "Eşitlik mi Ayrımcılık mı? Türkiye'de Sosyal Devlet, Cinsiyet Eşitliği Politikalarıve Kadın İstihdamı”. Çalışmave Toplum:41-54.

Dedeoğlu, Saniye ve Adem Yavuz Elveren (2012). Türkiyéde Refah Devleti ve Kadın. İstanbul: İletişim Yayınları.

Dudwick, Nora (2015). Missing Women" in the South Caucasus: Local perceptions and proposed solutions. World Bank.

Egamberdieva, Turgunoy (2016). "The Factors Increasing the Actıvity of Women in the Formation of State and Society in Uzbekistan”. The Advanced Science Journal 1: 47-51. 
European Bank (2015). Legal Barriers to Women's Participation in the Economy in the Kyrgyz Republic. www.ebrd.com/documents/admin/legal-barriers-gender.pdf (Erişim Tarihi: 10.10.2016).

FAO (2015). Gender and Land Statistics Recent developments in FAO's Gender and Land Rights Database. Rome.

UNDP (2007). Gender Attitudes in Azerbaijan Trends and Challenges. Azerbaijan Human Development Report 2007.

"Gender issues, Situation in the field of Gender Mainstreaming in the Republic of Azerbaijan”. http://www.mfa.gov.az/en/content/111, 2013. (Erişim Tarihi: 25.07.2016).

Geybullayev, Geybulla ve Erol Kurubaş (2002). “Türk Cumhuriyetlerinin Entegrasyonu: Fırsatlar, Sorunlar ve Çözüm Önerileri”. Süleyman Demirel Üniversitesi İktisadi ve İdari Bilimler Fakültesi 7(1): 19-45.

Gureyeva Aliyeva, Yuliya (2011). Policy Attitudes towards Women in Azerbaijan: Is Equality Part of the Agenda?, http://www.gwi-boell.de/en/2011/02/07/policyattitudes-towards-women-azerbaijan-equality-part-agenda (Erişim Tarihi: 29.07.2016)

Gureyeva-Aliyeva, Yulia ve Tabib Huseynov (2011). "Can you be an IDP for twenty years?" A compara tive field study on the protection needs and attitudes towards displacement among IDPs and host communities in Azerbaijan. Brookings Institution-London School of Economics Project on Internal Displacement. Baku.

Human Rights Watch Memorandum. Domestic violence in Kyrgyzstan https://www. hrw.org/legacy/pub/2008/eca/Kyrgyzstan_domestic_violence220908.pdf. (Erişim Tarihi: 20.09.2016).

Ibraeva, Gulnara, Anara Moldosheva ve Anara Niyazova (2012). World Development Report 2012 Gender Equality and Development. Background Paper, Kyrgyz Country Case Study.

İbrahim, Saima (2013). "Status of Women in Uzbekistan". IOSR Journal Of Humanities And Social Science 10 (3) (Mar. - Apr.): 47-55.

Ibrahimova, Sitara and Shahin Abbasov (2011) 'Azerbaijan: Baku confronting the issue of early marriage'. Eurasianet.org. 24 June 2011, http://www.eurasianet. org/node/63727 (Erişim Tarihi: 20.09.2016).

ILO (2013). Global Employment Trends for Youth: A generation at risk. Geneva.

ILO (2015). Labour Market Transitions of Young Women and Men Eastern Europe and Central Asia. Work4Youth Publication Series No. 28. 
Kapysheva, Aizhan (2014). The Analysis of Women's Marital Rights in Kazakhstan: Challenges of Gender Equality. Nazarbayev University.

Khatchvani, Tinatin (2015). The impact of gender-related stereotypes on intimate partner violence in the South Caucasus: Comparative study of Azerbaijan, Georgia and Armenia. Degree project in Criminology. 15 Credits. Malmö University: Faculty of Health and Society, Department of Criminology.

Mandl, Sabine (2011). Women in Azerbaijan Peace, Security and Democracy from a Women's Rights Perspective. Ludwig Boltzmann Institute of Human Rights.

Merhdiyeva, Günel (2015). "Violence against women in Azerbaijan: big challenge, weak policy”,http://policy-practice.oxfam.org.uk/blog/2015/04/violence-against-women-in-azerbaijan (Erişim Tarihi: 17.10.2016)

Myrzabekova, Altynai (2013) 'Kyrgyz politician gets her bride-theft law', Institute for War and Peace Reporting, 14 February 2013, http://iwpr.net/report-news/ kyrgyz-politician-gets-her-bride-theft-law, (Erişim Tarihi: 15.10.2016).

National Statistical Committee of the Kyrgyz Republic (2012). Women and Man in the Kyrgyz Republic 2007-2011 Compendium of Gender Disaggregated Statistics. Bishkek.

National Statistical Committee of the Kyrgyz Republic (2013). Women and Man in the Kyrgyz Republic 2008-2012 Collection of Gender-disaggregated Statistical Data. Bishkek.

Nazarbayev University, https://www.nottingham.ac.uk/hrlc/documents/student-conference-2014/aizhan-kapyshevawomen27s-rights-full-paper-pdf (Erişim Tarihi: 23.07.2016).

OECD (2014). Social Institution \& Gender Index KAZAKHSTAN, http://www.genderindex.-org/sites/default/files/datasheets/KZ.pdf (Erişim Tarihi: 15.08.2016).

Office of the United Nations High Commissioner for Human Rights (OHCHR) (2013) 'Azerbaijan - UN SR VAW Calls for Sweeping Accountability for Acts of Violence against Women', http://www.ohchr.org/EN/NewsEvents/Pages/ DisplayNews.aspx-?NewsID=14068 (Erişim Tarihi: 20.07.2016).

Rizvanova, Milyausha (2012). Sovyet Sonrası Orta Asya'da Kadın: Imaj ve Gerçeklik. Yüksek Lisans Tezi. İstanbul: İstanbul Üniversitesi.

Rosenberg, Chanie (1990). Kadınlar ve Perestroyka. Çev. Osman Akınhay. İstanbul: Pencere Yay.

Şafakcı, İnci Yelda. "Bağımsız Türk Cumhuriyetlerinde Sovyet Mirası”. https://www. academia.edu/5836945/Ba\%C4\%9F\%C4\%B1ms\%C4\%B1z_T\%C3\%BCrk_Cumhuriyetlerinde_Sovyet_Miras\%C4\%B1 (Erişim Tarihi: 18.10.2016) 
Sipahi, Esra Banu ve Bahar Özsoy (2016). Kadın Dostu Kent Imgesi, Sorunları ve Beklentileri Bağlamında Gaziantepli Kadınlar Üzerine Bir Araştırma. Ankara: Aktaş Ofset Matbaacilık.

State Committee on Women's Problems of the Republic of Azerbaijan (2004). Report in Response to a Questionnaire for Governments, Relating to the Implementation of the Beijing Platform for Action (1995) and the outcome documents of the 23rd special session of the General Assembly of the United Nations (2000). Baku: United Nations.

Statistical Commission and Economic Commission for Europe (2000). Turkmenistan Development of Gender Statıstıcs in Turkmenistan. Conference of European Statıstıcians Workıng Paper No. 16. Italy.

Submission to the United Nations Committee on the Elimination of Discrimination against Women (2012). Review of Turkmenistan under the Convention on the Elimination of All Forms of Discrimination against Women. Geneva. http://tbinternet.ohchr.org/Treaties/-CEDAW/Shared\%20Documents/TKM/ INT_CEDAW_NGO_TKM_13204_E.pdf (Erişim Tarihi: 18.10.2016). TC. Aile ve Sosyal Politikalar Bakanlığı Kadının Statüsü Genel Müdürlügü (2012). Türkiye'de Kadının Durumu. Ankara.

Tekinbaş, Ege (2015). Kadın Dostu Kentler Uygulama Rehberi. Ankara.

The Norwegian Helsinki Committee (2013). Women: Turkmenistan's Second-Class Citizens Equal only to injustice and vulnerable to arbitrariness. Oslo.

Tohid, Nayareh (1999). "Guardians of the Nation": Women, Islam and The Soviet Legacy of Modernization in Azerbaijan. Journal of Azerbaijani Studies. 63-97.

Toktayim, Umetalieva ve Elmira Aitkulova (2007). "The Role of Kyrgyz Government in the Promotion of Women's Rights". http://lib.icimod.org/record/12949/ files/1051.pdf (Erişim Tarihi: 18.10.2016).

Uludağ, İlhan ve Vildan Serin (1990). S.S.C.B. deki Türk Cumburiyetlerinin Sosyo - Ekonomik Analizleri ve Türkiye ile İlişkileri. İstanbul Ticaret Odası, Yayın No: 1990-22.

UN (2013). Post 2015 Development Agenda 'The Future We Want' National Consultations in Azerbaijan Final Report. Bakü.

UN (2015). The World's Women 2015 Trends and Statistics. New York.

UN Women (2015). Progress of the World's Women 2015-2016 Transforming Economies, Realizing Rights. United States

UNFPA (2015). UNFPA Country Programme Evaluation Azerbaijan Third country programme 2011-2015. 
U.S. Department of State (2015). "Azerbaijan 2015 Human Rights Report Executıve Summary". http://www.state.gov/j/drl/rls/hrrpt/humanrightsreport/\#wrapper (Erişim Tarihi:18.10.2016).

U.S. Department of State (2015). "Kyrgyz 2015 Human Rights Report Executıve Summaryhttp://www.state.gov/j/drl/rls/hrrpt/humanrightsreport/\#wrapper (Erişim Tarihi: 18.10.2016).

U.S. Department of State (2015). “Turkey 2015 Human Rights Report Executıve Summary”. http://www.state.gov/j/drl/rls/hrrpt/humanrightsreport/\#wrapper (Erişim Tarihi: 18.10.2016).

U.S. Department of State (2015). "Kazakıshtan 2015 Human Rights Report Executıve Summary”. http://www.state.gov/j/drl/rls/hrrpt/humanrightsreport/\# wrapper (Erişim Tarihi: 18.10.2016).

Women in National Parliament (2016). http://www.ipu.org/wmn-e/classif.htm (Erişim Tarihi: 18.10.2016).

Yussupov, Davron (2016). "Gender Statistics in the Republic of Uzbekistan, Statıstıcs Committee of the Republic of Uzbekıstan”. https:/www.unece.org/-fileadmin/DAM/stats/documents/ece/ces/ge.30/2016/WS/P5_Yusukov_ENG.pdf (Erişim Tarihi: 18.10.2016). 


\title{
The Problematic of Women in the Turkish Republics: Current Status of Women in the Turkic Republics in the Light of the International Reports*
}

\section{Bahar Özsoy ${ }^{* \star}$}

\begin{abstract}
With the collapse of the Soviet Union in the late twentieth century individual country gained independence in Central Asia and the Caucasus and in the intervening quarter of a century in these countries have occurred important political, economic and social changes. In particular, crises occurring in the economic and social fields affected deeply the lives of women, thus women's current positions have been shaped in the context of east-west, old-new stability-confusion. In the study, it was evaluated the national context in Turkey, Azerbaijan, Kazakhstan, Kyrgyzstan, Turkmenistan, Uzbekistan studies and applications which aimed at ensuring gender equality and international context with statistics related to women published in 2015 Human Development Report and Global Gender Gap Report.
\end{abstract}

\section{Keywords}

Turkish Republics, Gender Inequality Index, Human Development Report.

\footnotetext{
Date of Arrival: 20 October 2016 - Date of Acceptance: 01 March 2017 You can refer to this article as follows:

Özsoy, Bahar (2019). “Türk Cumhuriyetlerinde Kadın Sorunsalı: Uluslararası Raporlar Işığında Türk Cumhuriyetlerinde Kadınların Mevcut Durumu". bilig - Journal of Social Sciences of the Turkic World 89: 171-192.

“ PhD, Baku State University, International Relations - Baku/Azerbaijan ORCID ID: https://orcid.org/0000-0002-6667-6789 bhr_ozsoy_27@hotmail.com
} 


\title{
Проблемы женщин в тюркских
} республиках: современное положение женщин согласно международным

\author{
отчетам ${ }^{*}$
}

\section{Бахар Озсой}

\begin{abstract}
Аннотация
По прошествии четверти века после распада Советского Союза в обретших независимость странах Кавказа и Средней Азии произошли важные политические, экономические и социальные изменения, которые, в особенности в тюркских республиках, глубоко затронули жизнь женщин, заставляя оценивать их положение в контексте критериев запада и востока, нового и старого, стабильности и нестабильности. Данное исследование основано на национальных программах Турции, Азербайджана, Казахстана, Туркменистана и Узбекистана, направленных на равенство гендерных прав, а также на отчете о развитии человечества (Human Development Report) и международном отчете о гендерном неравенстве (Global Gender Gap Report).
\end{abstract}

\section{Ключевые слова}

Тюркские республики, индекс гендерного неравенства, отчет о развитии человечества

\footnotetext{
" Поступило в редакцию: 20 октября 2016 г. - Принято в номер: 01 марта 2017 г.

Ссылка на статью:

Özsoy, Bahar (2019). "Türk Cumhuriyetlerinde Kadın Sorunsalı: Uluslararası Raporlar Işığında Türk Cumhuriyetlerinde Kadınların Mevcut Durumu”. bilig - Журнал Гуманитарных Наук Тюркского Мира 89: 171-192

** Аспирантка, Бакинский государственный университет, отделение международных отношений, Баку/Азербайджан ORCID ID: https://orcid.org/0000-0002-6667-6789 bhr_ozsoy_27@hotmail.com
} 